\title{
САНІТАРНО-ОСВІТНЯ ГРАМОТНІСТЬ ЛЮДЕЙ - ОДИН ІЗ ВАЖЛИВИХ ЧИННИКІВ ЗНИЖЕННЯ РОЗПОВСЮДЖЕННЯ МУЛЬТИРЕЗИСТЕНТНОГО ТУБЕРКУЛЬОЗУ
}

\author{
Тернопільський державний медичний університет ім. І.Я. Горбачевського
}

За останні п'ять років (2010-2014рр.) значно почастішали мультирезистентний туберкульоз серед вперше діагностованих хворих і рецидиви. Вони відповідно зросли з 6,1 до 16,7 \% і з 23,8 до 44,2\%. Констатовано низьку санітарно-освітню грамотність хворих на мультирезистентний туберкульоз легень, які перебували на стаціонарному лікуванні не менше 2 міс. Результати анкетування показали слабку обізнаність більшості пацієнтів з основних питань туберкульозу, лише 38,8 \% респондентів відповіли правильно на запитання. Найнижчу поінфрормованість відмічено у хворих сільської місцевості та чоловічої статі, відповідно 49,4 і 47,7 \%.

Ключові слова: туберкульоз легень, мультирезистентність, санітарно-освітня робота.

Туберкульоз є однією з найактуальніших соціальнополітичних і медичних проблем у світі та в Україні зокрема. Тому дуже важливо інформацію про причини захворювання, його профрілактику і лікування, а також поведінку хворого в стаціонарі та в амбулаторних умовах всебічно доводити до широких мас населення і, зокрема, пацієнтів, хворих на туберкульоз. Ця недуга відома людству з далекої давнини, з доісторичних часів. У всі віки туберкульоз «косив» людей, заганяючи їх передчасно у могилу. Найбільші спалахи туберкульозу відбувалися з певною природною циклічністю - 25-50 років. Надзвичайно велика епідемія туберкульозу з високим рівнем летальності була в Європі у другій половині XIX століття, що привело до низки нових наукових відкриттів.

В 1995 р. епідемію туберкульозу зареєстровано в Україні. Ця епідемія має дві особливості: по-перше, спостерігається взаємозалежність швидкості розповсюдження туберкульозу від епідемії ВІЛ-інсрекції/СНІДу та поширення наркоманії, друга - високий рівень хіміозалежних фрорм - первинної до 30 \% та вторинної - до $75 \%$ у різних регіонах [1].

За даними ВООЗ, у світі майже 50 млн людей інфріковано резистентними до протитуберкульозних пре- паратів штамами мікобактерій туберкульозу. Щорічно збільшується кількість нових випадків туберкульозу 3 первинною медикаментозною стійкістю [2]. Україна посідає друге місце в Європі за темпами зростання мультирезистентного туберкульозу та четверте у світі за його поширеністю у вперше виявлених хворих. При резистентності збудника туберкульозу до протитуберкульозних препаратів I ряду виліковуються за допомогою препаратів II ряду тільки 50 \% хворих, $10 \%$ - помирають, а у $40 \%$ хворих туберкульоз набуває хронічного перебігу, при якому тривалість життя пацієнтів становить, у середньому, 2-5 років. При чутливості мікобактерій туберкульозу до антимікобактерійних препаратів виліковування сягає $95 \%$ [3].

Хіміорезистентність $€$ наслідком неправильного застосування протитуберкульозних препаратів (низькі дози, неконтрольоване лікування, перерви в лікуванні тощо). Через те вважається, що хіміорезистентність $€$ проблемою, створеною лікарями та пацієнтами.

Поширення мультирезистентності мікобактерій туберкульозу небезпечне тим, що недуга переходить в категорію невиліковних, звичайно, якщо не будуть синтезовані нові ефективні протитуберкульозні препарати. За останні 40 років отримано новий препарат для лікування хворих на мультирезистентний туберкульоз. Це бедаквілін, який впливає на життєдіяльність збудника шляхом пригнічення аденозинтрифроссратсинтетази (АТФ-синтетази) - фермент, який необхідний для енергозабезпечення клітин бактерії. Ефективність бедаквіліну - 57,6\%.

До слова, слід пам'ятати, що хворий на деструктивний туберкульоз легень може виділяти з мокротинням від 15 млн до 7 млрд мікобактерій протягом доби, і про те, що найнебезпечніше повітряно-краплинне інфрікування, передусім - пилова інсрекція. Висохлі крапельки мокротиння на підлозі, різних предметах піднімаються в повітря у вигляді інфікованого пилу. Чим менші ці частинки, тим більша ймовірність, що вони через дихальні шляхи досягнуть альвеол, позбавлених місцевого захисту. 
Лікування хворих на туберкульоз у теперішній час проводиться згідно з уніфікованим клінічним протоколом медичної допомоги (УКМПД) «Туберкульоз» (2014) [4]. Стаціонарне лікування хворих триває до припинення бактеріовиділення, що підтверджується методом мікроскопії мазка мокротиння. Подальша терапія проводиться в амбулаторних умовах під «медичним» наглядом, що не $є$ достатньо ефективним, оскільки загоєння порожнин розпаду відбувається лише у 63,1 \% хворих на вперше виявлений деструктивний туберкульоз легень, а з деструктивними рецидивами - у 41,3 \%. Решта неефективно пролікованих пацієнтів $€$ мультирезистентними «хроніками» і становлять особливо небезпечну епідеміологічну загрозу [5]. 3 цього випливає, що на відміну від унітарної, слід дотримуватися більш гнучкої програми лікування, яка передбачає для різних контингентів хворих різні методи та організаційні форми. В цьому плані вже внесено деякі зміни до Унітарного клінічного протоколу за темою «Туберкульоз» [6]. Основною версією протоколу дозволено розпочинати лікування хворих на туберкульоз через 3-5 днів після проведення обстеження шляхом застосування молекулярно-генетичної діагностики та забезпечення лікування туберкульозу в амбулаторних умовах. На базі протитуберкульозного стаціонару чи санаторію можливо організовувати відділення паліативної допомоги для хворих на туберкульоз або хоспіс 3 метою цілодобового кваліфрікованого догляду, надання медичної, соціальної, духовної та психологічної допомоги пацієнтам на хіміорезистентний туберкульоз. Під час фрази продовження асоціальні хворі, одинаки чи безхатченки, якщо їм неможливо забезпечити контрольоване лікування амбулаторно, то вони можуть продовжити лікування у стаціонарі чи санаторії за соціальними показаннями. У вогнищах мультирезистентного туберкульозу хіміопрофрілактика повинна проводитися не ізоніазидом, а хіміопрепаратами, до яких чутливість мікобактерії збережена у джерела інсрекції.

Важливо акцентувати увагу на те, що виписка хворих 3 незагоєними порожнинами розпаду на амбулаторне лікування, зокрема паліативне, створює велику загрозу розповсюдження туберкульозної інфекції, передусім мультирезистентного туберкульозу, серед членів сім'ї, близького оточення і населення в цілому [7]. Смертність хворих у домашніх умовах повинна бути зведена до мінімуму. В Тернопільській області за 2013 р. вона становила 25,4 \%. До слова, у США 75-85 \% усіх смертей трапляються у лікарнях, тобто лікарі до останнього борються за життя людини, надаючи їм необхідну допомогу. В Україні приблизно стільки ж смертей відбуваються вдома - лікарська статистика не псується, але ж чи легше від того хворим [8]?
Надзвичайно важливою складовою протитуберкульозної роботи в теперішній час $€$ санпросвітня робота серед хворих на туберкульоз, контактів і населення в цілому. Санпросвітня робота - це безперервний процес, який полягає у висвітленні властивостей збудника туберкульозу, шляхів його передачі, проявів захворювання, лікування та профрілактики. На жаль, санпросвітня робота проводиться на неналежному рівні, передусім індивідуальна, серед пацієнтів. 3 цього випливає і низька прихильність до лікування [7].

Мета роботи - 3'ясувати рівень і підвищити санпросвітню грамотність, зокрема хворих на мультирезистентний туберкульоз.

\section{Матеріали і методи}

Наведені результати бактеріологічних досліджень, чутливості мікобактерій туберкульозу до антимікобактерійних препаратів (АМБП) І ряду, за 2010-2014рр., результати лікування хворих на вперше виявлений туберкульоз і рецидиви, а також анкетування 70 пацієнтів на мультирезистентний туберкульоз легень з основних питань з цієї недуги.

\section{Результати досліджень та їх обговорення}

Однією з надзвичайно важливих проблем нашого регіону $€$ значне почастішання хіміорезистентного туберкульозу - як у хворих на вперше діагностований туберкульоз, так і рецидиви, зокрема на мультирезистентний туберкульоз. Це найнебезпечніша фрорма туберкульозу, при якій мікобактерії $є$ стійкими до двох найефективніших протитуберкульозних препаратів: ізоніазиду та рифрампіцину, а самі мікобактерії мають більшу вірулентність і набагато легше передаються від хворої людини до здорової. Такий туберкульоз вимагає обов'язкової госпіталізації та ізоляції хворого на строк від 18 до 24 міс., тобто лікування триває втричі довше, ніж звичайних фрорм туберкульозу, і потребує від держави значних коштів. Лікування $є$ доволі токсичним для пацієнта та менш ефективним.

У таблиці 1 наведено частоту резистентності мікобактерій туберкульозу у хворих Тернопільської області (2010-2014 рр.) на вперше діагностований туберкульоз легень.

Як випливає з таблиці 1, хіміорезистентність до 4-х препаратів I ряду за останні 5 років значно зросла і, передусім, мультирезистентність - 36,1 до 16,7 \% (p<0,05). Це надзвичайно тривожна епідеміологічна ситуація, яка свідчить про те, що кожний 6-й вперше діагностований хворий на туберкульоз мультирезистентний. Причиною такої первинної резистентності $€$ хворі на хронічні фрорми та рецидиви бактеріовиділювачі, які знаходяться поза стаціонаром і, переважно, не лікуються. Тому всі бактеріовиділювачі повинні знаходитися в стаціонарних умо- 
вах до стійкого припинення бактеріовиділення, підтвердженого не лише за результатами негативної мікроскопії, a і за негативним посівом мокротиння i, в переважній більшості, з ліквідацією порожнини розпаду. ще значно вища хіміорезистентність, зокрема мультирезистентність, констатована у хворих з рецидивами (табл. 2).

Таблиця 1

Хіміорезистентність хворих на вперше діагностований туберкульоз легень (\%)

\begin{tabular}{|c|c|c|c|c|c|c|}
\hline \multicolumn{2}{|c|}{ Рік } & 2010 & 2011 & 2012 & 2013 & 2014 \\
\hline \multicolumn{2}{|c|}{ Абс. число хворих } & 244 & 252 & 234 & 248 & 252 \\
\hline \multirow{3}{*}{$\begin{array}{c}\text { Стійкість до } \\
\text { АМБп }\end{array}$} & $\mathrm{H}+\mathrm{R}$ & 6,1 & 5,6 & 12,4 & 10,9 & 16,7 \\
\cline { 2 - 7 } & $\mathrm{H}$ & 19,3 & 17,1 & 27,4 & 24,2 & 31,3 \\
\cline { 2 - 7 } & $\mathrm{R}$ & 8,6 & 7,1 & 15,8 & 13,3 & 19,8 \\
\cline { 2 - 7 } & $\mathrm{E}$ & 7,0 & 6,0 & 12,8 & 10,5 & 14,7 \\
\cline { 2 - 7 } & $\mathrm{S}$ & 27,0 & 32,5 & 22,2 & 21,4 & 31,0 \\
\hline
\end{tabular}

Таблиця 2

Хіміорезистентність хворих з рецидивами туберкульозу легень (\%)

\begin{tabular}{|c|c|c|c|c|c|c|}
\hline \multicolumn{2}{|c|}{ Рік } & 2010 & 2011 & 2012 & 2013 & 2014 \\
\hline \multicolumn{2}{|c|}{ Абс. число хворих } & 42 & 38 & 62 & 107 & 95 \\
\hline \multirow{3}{*}{$\begin{array}{c}\text { Стійкість до } \\
\text { АМБп }\end{array}$} & $\mathrm{H}+\mathrm{R}$ & 23,8 & 28,9 & 33,9 & 34,6 & 44,2 \\
\cline { 2 - 7 } & $\mathrm{H}$ & 42,9 & 44,7 & 48,4 & 50,5 & 55,8 \\
\cline { 2 - 7 } & $\mathrm{R}$ & 26,2 & 34,2 & 38,7 & 38,3 & 47,4 \\
\cline { 2 - 7 } & $\mathrm{E}$ & 19,0 & 13,2 & 27,4 & 24,3 & 34,7 \\
\cline { 2 - 7 } & $\mathrm{S}$ & 35,7 & 44,7 & 51,6 & 49,5 & 53,7 \\
\hline
\end{tabular}

3 таблиці 2 видно, що за останні 5 років значно зросла хіміорезистентність мікобактерій туберкульозу у пацієнтів з рецидивами, в тому числі мультирезистентність. Еорективність лікування таких хворих доволі низька. Більшість з них переходять у групу «хроніків» або помирають.

Результати лікування хворих на деструктивний туберкульоз легень з різною чутливістю мікобактерій за 2010-2013 рр. наведені в таблиці 3.

Таблиця 3

Результати лікування хворих на туберкульоз легень з деструкцією

\begin{tabular}{|c|c|c|c|c|c|c|c|c|}
\hline \multirow{2}{*}{ Тип випадків / Рік } & \multicolumn{2}{|c|}{ К-сть хворих з деструкцією на початку лікування } & \multicolumn{3}{|c|}{ К-сть хворих, у яких деструкція загоїлася } \\
\cline { 2 - 9 } & 2010 & 2011 & 2012 & 2013 & 2010 & 2011 & 2012 & 2013 \\
\hline $\begin{array}{c}\text { Вперше виявлені } \\
\text { хворі }\end{array}$ & 242 & 235 & 219 & 180 & $\begin{array}{c}147 \\
60,7 \%\end{array}$ & $\begin{array}{c}154 \\
65,5 \%\end{array}$ & $\begin{array}{c}153 \\
69,9 \%\end{array}$ & $\begin{array}{c}123 \\
68,3 \%\end{array}$ \\
\hline Рецидиви & 41 & 39 & 59 & 84 & $\begin{array}{c}17 \\
17\end{array}$ & $\begin{array}{c}16 \\
27\end{array}$ & $\begin{array}{c}25 \\
62,7 \%\end{array}$ & $29,8 \%$ \\
\hline
\end{tabular}

Загалом, в Україні ефрективність лікування хворих на мультирезистентний туберкульоз (за 2010 р.) становить лише 29 \%. До того ж, хворі 3 хіміорезистентним туберкульозом, яким призначено паліативне лікування без чітко врегульованого й достатнього соціального й медичного супроводу, взагалі залишаються поза увагою, чим і зумовлюють неконтрольоване поширення збудника туберкульозу [9]. Серед причин низької еорективності лікування хворих на туберкульоз, зокрема мультирезистентний, найважливішою є низька прихильність їх до лікування. А це зумовлено незадовільною санітарною грамотністю населення і хворих зокрема. 
Результати анкетування 70 пацієнтів на хіміорезистентний туберкульоз легень, які перебували на стаціонарному лікуванні понад 2 міс., показали дуже слабку обізнаність з туберкульозу. Лише 38,8 \% респондентів відповіли правильно на запитання. Найнижча поінформованість з питань туберкульозу констатована у хворих сільської місцевості та чоловічої статі, відповідно 49,4 і 47,7 \%. Це надзвичайно негативно відображається на епідеміології та результатах лікування особливо небезпечної форми - мультирезистентного туберкульозу.

Без значного покращення обізнаності хворих щодо питань боротьби з туберкульозом очікувати позитивних результатів буде неможливо. Це святий обов'язок, у першу чергу фртизіатрів, щодо покращення санітарноосвітніх знань серед хворих, як і населення загалом. На запитання, передусім з якого джерела хворі на мультирезистентний туберкульоз хотіли б отримувати інфрормацію про туберкульоз, більшість (55,7%) 3 них відповіли, що безпосередньо від свого лікуючого лікаря. Отож, основна відповідальність за проведення санітарно-освітньої роботи лежить на фртизіатрах. До того ж, лікар-сртизіатр повинен бути, до певної міри, і психологом. Настав час проводити спеціальні курси по психології фртизіатрів, оскільки, не в образу, звичайні психологи не мають належного життєвого досвіду в боротьбі з туберкульозом і вони не спроможні прищепити глибоку прихильність, зокрема, до тривалого лікування. Крім цього, слід залучати до проведення санпросвітньої роботи, бесід і субординаторів та інтернів у палатах хворих, зокрема, на мультирезистентний туберкульоз. Поряд з тим, потрібно значно ширше і активніше використовувати й інші традиційні форми санпросвітньої роботи.

У хворих з низькою прихильністю до лікування, недисциплінованих, шляхом проведення індивідуальної, продуманої, наполегливої та доброзичливої роботи можна значно покращити прихильність до лікування та дотримання санітарно-гігієнічних норм. Адже хворий активно лікується, виконує всі настанови лише у того лікаря, кому довіряє. 3 ним пацієнт підтримуватиме зв'язки, радитиметься навіть після одужання. Там, де добре налагоджена індивідуальна психологічна робота 3 хворими, встановлено доброзичливий контакт, лікування відбувається у сприятливій атмосфері та 3 позитивним наслідком. Суворі дисциплінарні заходи, погрози, грубі, травмуючі вислови і висновки не завжди приводять до належних позитивних результатів. Отож, важливою складовою протитуберкульозної роботи є санпросвітня робота серед хворих на туберкульоз, контактів і населення в цілому. Санітарно-просвітня робота - це безперервний процес, який полягає у висвітленні, передусім лікарямифртизіатрами, властивостей збудника туберкульозу, шляхів його передачі, проявів захворювання, методів лікування, профрілактики і, загалом, здорового способу життя людини.

\section{Висновки}

1. За останні п'ять років (2010-2014 рр.) констатовано значне почастішання мультирезистентного туберкульозу серед вперше діагностованих хворих і рецидивів, відповідно 3 6,1 до 16,7 \% і з 23,8 до 44,2 \%.

2. Різке зростання кількості хворих на мультирезистентний туберкульоз легень зумовлено, певною мірою, зарегламентованими організаційними орормами боротьби з туберкульозом і низькою прихильністю до лікування хворих внаслідок недостатньої санітарної грамотності пацієнтів.

3. Результати анкетування 70 хворих на мультирезистентний туберкульоз легень засвідчили слабку орієнтацію їх з основних питань туберкульозу, лише 38,8 \% респондентів правильно відповіли на запитання. Найнижча поінорормованість констатована у хворих сільської місцевості та чоловічої статі, відповідно у 49,4 i $47,7 \%$.

\section{Література}

1. Мельник В.М. Історія виникнення і розвитку хіміорезистентного туберкульозу / В.М. Мельник, А.М. Приходько, Л.В. Ареср'єва // Укр. пульмонол. журн. - 2012. - № 2. - С. 59-61.

2. Тодоріко Л.Д. Особливості епідемії та патогенезу хіміорезистентного туберкульозу на сучасному етапі / Л.Д. Тодоріко // Клиническая иммунология. Аллергология. Иноектология. -2011. - № 4. - С. 38-41.

3. Черенько С.О. Проблема хіміорезистентного туберкульозу / С.О. Черенько [Електронний ресурс]. - Режим доступа : http:// www. ifp.kiev.ua/doc/people/tubrezist.htm.

4. Унісрікований клінічний протокол первинної, вторинної (спеціалізованої) та третинної (високоспеціалізованої) медичної допомоги дорослим. Туберкульоз. - 2014. - 179 с.

5. П'ятночка І.Т. Про рецидиви туберкульозу легень / І.Т. П'ятночка, С.І. Корнага, Н.В. Тхорик // Вісник наукових досліджень. - 2014. - № 2. - С. 53-54.

6. Організація виявлення та лікування хворих на хіміорезистентний туберкульоз: методичні рекомендації. - Київ, 2014.

7. П'ятночка І.Т. Шляхи зниження розповсюдження мультирезистентного туберкульозу з погляду фртизіоепідеміології / І.Т. П'ятночка, С.І. Корнага, Н.В. Тхорик // Вісник соціальної гігієни та організації охорони здоров'я України. - 2014. - № 4. - С. 67-71.

8. Петренко В.І. До міжнародного дня боротьби з туберкульозом: «Охопити три мільйони: виявити, лікувати, вилікувати туберкульоз» / В.І. Петренко // Туберкульоз, легеневі хвороби, ВІЛ-інфекція. - 2014. - № 1. - С. 5-7.

9. Писаренко Ігор. Локомотив чи дзеркало української медицини? / Ігор Писаренко // Медична газети України. Ваше здоров'я. - 2013. - № 49-50. - С. 12-13. 


\section{SANITARY-EDUCATION OF PEOPLE - REDUCE THE SPREAD OF MULTI- RESISTANT TUBERCULOSIS AS IMPORTANT FACTORS}

S.I. Kornaha, I.T. Pyatnochka, N.V. Tkhoryk

SUMMARY. For the last five years (2010-2014) multiresistant tuberculosis among the first diagnosed patients and relapses became more frequent considerably. MDR accordingly grew from 6,1 \% to 16,7\% and from 23,8 \% to $44,2 \%$. It notes that low health literacy and academic patients with MDR tuberculosis who were hospitalized for at least 2 months. The results of questionnaire showed a weak awareness to most patients on basic questions of tuberculosis, only 38,8 \% respondents answered a question correctly. Most subzero being informed it is marked for the patients of rural locality and sex of men, according to $49,4 \%$ and $47,7 \%$.

Key words: tuberculosis, multi-resistant (MRD), sanitary-educational work.

Отримано 19.10.2015 p. 